\title{
MINERALOGIA DOS MUIRAQUITÃS DO ACERVO DO MAE-USP
}

Nos dias 26 e 27 de maio de 1998, estivemos visitando as dependências do MAE, no campus da USP, em São Paulo, com a finalidade de coletar amostras de alguns artefatos líticos pertencentes ao acervo desse museu - os muiraquitãs - visando a caracterização mineralógica e química desses materiais. Esse estudo faz parte de um projeto maior que visa estudar a procedência de artefatos líticos em jade/nefrita na região amazônica, e que vem sendo desenvolvido pelo grupo de Mineralogia Aplicada na Amazônia - GMA, do Centro de Geociências da Universidade Federal do Pará. O GMA é coordenado pelo Prof. Dr. Marcondes Lima da Costa, que também esteve visitando o MAE em 24 de abril de 1998, e fez os primeiros contatos, através do Dr. Eduardo Góes Neves, para que essa coleta de material pudesse ser realizada. A seguir será feita uma breve descrição dos procedimentos adotados e da metodologia de análise a ser utilizada:

O trabalho consistiu basicamente em se obter pequenas quantidades (pó) dos objetos líticos de interesse, que foram extraídas utilizando-se uma mini-broca elétrica ou "besouro", imergindo-se a peça, ou uma parte dela, em álcool, em um recipiente de vidro de fundo chato. No caso dos muiraquitãs, o desgaste é feito aproveitando-se orifícios pré-existentes nas peças, para que não haja qualquer tipo de danos ao material.

Procedeu-se então a um processo de abrasão ou escareamento da superfície, de tal modo que o pó resultante desse desgaste ficasse em suspensão na solução. $\mathrm{O}$ álcool tem ainda a finalidade de lubrificar a broca, evitando superaquecimento. A solução contendo o pó em suspensão foi então aquecida em chapa térmica, evaporando todo o álcool e precipitando o material no fundo do recipiente. $\mathrm{O}$ mesmo pôde então ser raspado com uma gillete e armazenado em recipientes de vidro para análises mineralógicas e químicas.

Retornando a Belém, as amostras foram encaminhadas para análise meneralógica por difração de raios-x. O equipamento utilizado é um difratômetro da marca Philips PW 3710 e goniômetro PW 1050, com tubo de anodo de $\mathrm{Cu}(45 \mathrm{kV}, 40 \mathrm{~mA}$ e radiação
$\mathrm{CuK} \alpha_{1}-1,54050 \AA$ ) , fenda de divergência de $1^{\circ}$, fenda de recepção de $0,2 \mathrm{~mm}$ e monocromador de grafite. As análises estão sendo realizadas em amostra total (método do pó), com 20 variando de 5-65', em steps de $0,02^{\circ}$. Os resultados (difratogramas) são apresentados em arquivos em disco, para tratamento e interpretação com softwares específicos. A identificação mineralógica nas fichas do JCPDS é efetuada através do sistema $A P D$, também da Philips.

As amostras estão sendo encaminhadas para análise por Microscopia Eletrônica de Varredura (MEV) com Sistema de Energia Dispersiva (SED), o que permitirá a obtenção de fotomicrografias de detalhe dos aspectos microtexturais do(s) mineral(is) constituintes dos artefatos líticos, assim como a determinação da composição química.

A grande vantagem da utilização desses métodos é de eles se valerem de pequeníssimas quantidades de material $(10 \mathrm{mg})$ para uma caracterização mineralógica e química de alta precisão. No passado, seriam necessárias várias gramas de material para se obter tais resultados, o que implicaria, inevitavelmente, na destruição de grande parte da peça. É assim que se optava por uma descrição macroscópica generalizada desses materiais, a ter que destruí-los para saber a sua real composição.

Para finalizar, vale lembrar que esse tipo de intercâmbio entre arqueólogos e geólogos e/ou mineralogistas não é novo, onde diferentes técnicas de caracterização mineralógica e química que eram tradicionalmente aplicadas a materiais geológicos, vêm sendo aplicadas com sucesso em cerâmicas, objetos líticos e pinturas arqueológicas. Adicionalmente, diversos trabalhos também têm sido realizados envolvendo a aplicação das técnicas de prospecção geoquímica e geofísica, na localização e caracterização de sítios arqueológicos.

Estudos desta natureza abrem um grande espaço de trabalho e intercâmbio nas áreas da arqueologia e geologia, na caracterização dos acervos de diversos museus e estudos de proveniência ou áreafonte de materiais arqueológicos.

Rômulo Simões Angélica*

(*) Centro de Geociências, Mineralogia Aplicada, Universidade Federal do Pará. 